ACCOUNTING : an introduction 


\section{Accounting: \\ an introduction}

Arthur HINDMARCH

Miles ATCHISON

Richard MARKE 
(C) Arthur Hindmarch, Miles Atchison, Richard Marke 1977 Softcover reprint of the hardcover 1st edition 1977 978-0-333-15023-8

All rights reserved. No part of this publication may be reproduced or transmitted, in any form or by any means, without permission

First published 1977 by

THE MACMILLAN PRESS LTD

London and Basingstoke Associated companies in New York Dublin Melbourne Johannesburg and Madras

ISBN 978-0-333-19167-5 ISBN 978-1-349-15639-9 (eBook)

DOI 10.1007/978-1-349-15639-9

Text set in 10/11 pt Photon Baskerville

This book is sold subject to the standard conditions of the Net Book Agreement.

The paperback edition of this book is sold subject to the condition that it shall not, by way of trade or otherwise, be lent, resold, hired out, or otherwise circulated without the publisher's prior consent in any form of binding or cover other than that in which it is published and without a similar condition including this condition being imposed on the subsequent purchaser. 


\section{Editor's Introduction}

This series is a direct outcome of the opportunities and challenges created by the rapid expansion of higher and further education in the past decade.

The expansion involved changes in the structure of advanced education, through the CNAA, the Polytechnics, the Regional Management Centres and the professional bodies which encouraged staff to develop new and experimental teaching. Substantial changes have taken place in the definition, scope and methodologies of the social, administrative and management sciences leading to modifications in the presentation of these subjects. Many new full-time students and staff have questioned traditional approaches and methods and have established more open discussion and debate on their courses. Demands for qualified manpower led to an expansion in part-time education and increased questioning by students in full-time jobs of the relevance of their studies.

Each of these developments has had a profound impact on the structure and content of courses and given fresh impetus to the discussion and modification of curricula and teaching methods in polytechnics, universities and colleges of further education. The editor and authors of the books in this series have made a deliberate attempt to respond to these changes.

The books set out to provide a comprehensive and up-to-date introduction to the ideas and methods of their subjects for specialist and non-specialist students in fields such as business and management studies, social science and administration. Their aim is to help students who have little or no previous knowledge of them to achieve a mastery of the scope and basic techniques of their subjects and to use them critically and with imagination for further study or for practical professional applications. They also seek to make some contribution to discussions of teaching and learning problems in their field.

Many introductory books present their subjects as a coherent body of knowledge of which the logic is self-evident and the concepts and methods clear to the careful reader. Students do not always find this so. Confronted as they are by a well-established discipline which has developed a particular method that may not bear any obvious relationship to the way in which they have been accustomed to think or to realities as they see them, students often have difficulty in comprehending the significance and detail of the forms of analysis it employs.

The editor and authors of the series felt that they should not take for granted the 'self-evident logic' of their subjects, but try to demonstrate to readers the ways in which their disciplines provide an effective framework for the analysis of problems in their field. When abstractions or concepts are introduced their functions and limitations are explained. Where methods or techniques are described the authors 
show why they take the form they do and the ways in which they may be used for particular tasks of analysis.

Students often criticise courses because their subjects or parts of them do not have any obvious, or immediate, practical applications. They may present what appear to be unnecessarily complicated ways of dealing with quite straightforward problems or, paradoxically, they may be regarded as over-simplifying or ignoring difficulties which are experienced in real situations. Criticisms of this sort are due to misunderstandings about the nature of subjects. Systems of knowledge provide generalisations which are derived from a variety of abstractions and models. Some of these yield tools of description and analysis that have direct applications. Others suggest ways of looking at problems that, however fruitful, may have only limited or indirect applications.

The authors have tried to make clear the relevance of their subjects. Where concepts and methods have direct applications they show how, and under what circumstances, they can usefully be applied. Where they are of indirect use they show how a process of simplification may isolate and draw attention to the important characteristics of a complex problem, or how the study of complicated or abstract aspects of a problem may throw fresh light on it.

The authors have rejected a view, reflected in many basic textbooks, that students at an introductory level should concentrate on 'learning up' the information and techniques of their subjects and not be troubled with discussions of concepts and analytical method. This 'descriptive' approach, which divorces the study of techniques from that of conceptual and analytical structures, makes it more rather than less difficult for students to appreciate how a technique has developed, why it takes a particular form and how it functions. As a result students can spend a considerable time trying to understand, with limited success, a method of describing and presenting information or a method of analysis and fail to achieve any real facility in using it. The discussion of concepts and analytical method also acquaints a student with some of the difficulties and controversies surrounding the ideas and techniques he is studying. Without such knowledge he is unlikely to appreciate their limitations or establish any real ability to discriminate between alternative approaches and methods.

One of the more important aims of education is to develop a student's capacity to formulate and solve theoretical and practical problems. It is clear that few business and administrative problems are in practice separable into the neat categories represented by disciplines such as economics, accounting, law, sociology, psychology and computing. But most courses are based on combinations of studies in these and similar discrete disciplines which are rarely effectively integrated. It is recognised that the development of bodies of knowledge which provide rigorous rather than superficial integrative approaches will be a long and difficult task. The editor and authors of the books in this series are aware of this problem and within their limitations have attempted to indicate points at which contributions from other disciplines are necessary to the analysis of the problems with which they are dealing. It is thus hoped that in the long run the series will make some contribution to the development of interdisciplinary approaches.

The problems outlined above are common in the teaching and learning of many subjects which, although emerging historically as systems for analysing and solving practical problems, have developed advanced methodologies and a logical order of presentation that may not bear an obvious relation to the practical problems with which they are supposed to be concerned.

The study of accounting appears to many to approximate closely to the actual 
practices and problems of the accounting profession. And yet many students have great difficulty in grasping its methods of analysing and presenting data. Perhaps this is due to a general problem of numeracy and an inability to understand relationships between variables presented in a quantitative form. Or perhaps it is that the student has in his early stages to study many complex methods of presenting data which can only at a later stage be used for more interesting and complete analyses of the economic performance of organisations. The power of the concepts and tools of accounting to analyse and explain the structure and operations of an organisation should, however, be of interest to anyone who follows economic and business affairs. It is hoped that the present exposition, by helping students to achieve a more effective command of modern basic accounting, will encourage them to investigate further its methodology and potential.

The editor and authors of the books in this series are conscious of their limitations in attempting to implement their ideas in writing and teaching and do not suppose that their presentation will solve students' learning problems. They do not ignore the critical importance of motivation and sustained and disciplined study as factors in effective learning. But they felt that if subjects were presented in a way that made their form and justification explicit rather than implicit this would aid teaching and learning.

In seeking to achieve their aims the books in the series have been subjected to a great deal of critical scrutiny. Each is written by more than one author. This has enabled authors to combine a comparison of views with a considerable, and sometimes uncomfortable, degree of mutal criticism. The editor and authors have all, in recent years, had considerable experience of designing and teaching new CNAA honours degree, diploma or professional courses. Their manuscripts have been discussed with colleagues in education and the professions and have been tested in classes with students.

My thanks as editor are owed to the authors who responded to my request to write the books in the form that I have outlined. This has involved them in an extremely demanding process. The fact that we shared some basic assumptions about education and learning was of great help. The editors and staff of Macmillan with whom we have worked have showed great patience and could not have done more in difficult circumstances to encourage the series. My thanks are also due to George Brosan, Maurice Peston and Bruce May, who through many discussions have significantly influenced my educational ideas, and to my wife Diane, who has kept a discerning eye on my activities and the progress of the series.

February 1976

Alan Hale 


\section{Contents}

Editor's Introduction $\quad \mathrm{v}$

Introduction $\quad \mathrm{xv}$

PART I MEASUREMENT

Chapter 1 Concepts of value and profit 3

1.1 Introduction 3

1.2 Objectives of measurement 3

1.3 Introduction to value and profit 5

1.4 The concept of value 6

$\begin{array}{ll}1.5 \text { The concept of profit } & 11\end{array}$

$\begin{array}{ll}1.6 \text { Accounting statements } & 13\end{array}$

$\begin{array}{lll}1.7 & \text { Summary } & 15\end{array}$

$\begin{array}{ll}\text { Notes and references } & 16\end{array}$

$\begin{array}{ll}\text { Further reading } & 16\end{array}$

$\begin{array}{ll}\text { Questions and problems } & 17\end{array}$

$\begin{array}{lll}\text { Chapter } 2 \text { Accounting concepts } & 18\end{array}$

$\begin{array}{ll}2.1 \text { Introduction } & 18\end{array}$

$\begin{array}{ll}2.2 \text { Need for a conceptual framework } & 18\end{array}$

$\begin{array}{ll}2.3 \text { Development of a conceptual framework } & 19\end{array}$

$\begin{array}{ll}2.4 \text { Content of a conceptual framework } & 21\end{array}$

2.5 The concepts defined and illustrated 23

$\begin{array}{ll}2.6 & \text { The concepts evaluated } \\ 2.7 & 25\end{array}$

$\begin{array}{lll}2.7 & \text { Summary } & 27\end{array}$

$\begin{array}{ll}\text { Notes and references } & 27\end{array}$

$\begin{array}{ll}\text { Further reading } & 27\end{array}$

$\begin{array}{ll}\text { Questions and problems } & 28\end{array}$

$\begin{array}{lll}\text { Chapter } 3 & \text { The structure of accounting data } & 29\end{array}$

$\begin{array}{ll}3.1 \text { Introduction } & 29\end{array}$

$\begin{array}{ll}3.2 \text { Fundamental accounting equation } & 29\end{array}$

3.3 Examples of analysis using the fundamental

$\begin{array}{ll}3.4 \text { Owners' equity } & 31\end{array}$

3.5 Assets and expenses $\quad 34$

3.6 Analysis of accounting data for financial statements $\quad 35$ 
3.7 Presentation of the balance sheet

3.8 Presentation of the profit statement 40

3.9 Profit and cash flow 41

3.10 Summary $\quad 43$

Notes and references $\quad 43$

$\begin{array}{ll}\text { Further reading } & 43\end{array}$

$\begin{array}{ll}\text { Questions and problems } & 43\end{array}$

Chapter 4 The processing of accounting data $\quad 45$

4.1 Introduction $\quad 45$

4.2 Double-entry book-keeping $\quad 45$

$\begin{array}{lll}4.3 & \text { Double-entry procedures } & 48\end{array}$

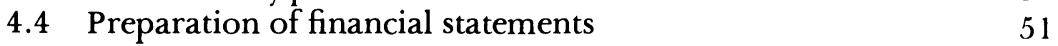

4.5 Total accounts $\quad 55$

\begin{tabular}{ll}
4.6 & Classification of accounting data \\
\hline
\end{tabular}

4.7 Information and accounting systems $\quad 56$

$\begin{array}{lll}4.8 & \text { Summary } & 58\end{array}$

Notes and references $\quad 59$

$\begin{array}{lr}\text { Further reading } & 59\end{array}$

Questions and problems $\quad 59$

$\begin{array}{lll}\text { Chapter } 5 \text { Fixed assets } & 61\end{array}$

$\begin{array}{lll}5.1 \text { Introduction } & 61\end{array}$

$\begin{array}{lll}5.2 \text { Value considerations } & 61\end{array}$

$\begin{array}{lll}5.3 & \text { Depreciation } & 62\end{array}$

5.4 Depreciation using original cost 63

$\begin{array}{lll}5.5 & \text { Recording depreciation information } & 71\end{array}$

$\begin{array}{lll}5.6 & \text { Depreciation and replacement } & 72\end{array}$

$\begin{array}{lll}5.7 & \text { Non-physical fixed assets } & 73\end{array}$

$\begin{array}{lll}5.8 & \text { Summary } & 73\end{array}$

$\begin{array}{ll}\text { Notes and references } & 73\end{array}$

$\begin{array}{ll}\text { Further reading } & 74\end{array}$

$\begin{array}{ll}\text { Questions and problems } & 74\end{array}$

$\begin{array}{lll}\text { Chapter } 6 \text { Costing and inventory } & 76\end{array}$

$\begin{array}{lll}6.1 \text { Introduction } & 76\end{array}$

$\begin{array}{lll}6.2 \text { Cost classifications } & 77\end{array}$

$\begin{array}{lll}6.3 & \text { Cost systems } & 82\end{array}$

6.4 Inventory valuation and profit measurement $\quad 88$

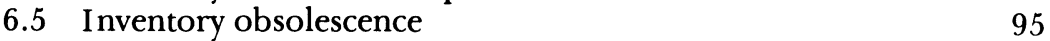

$\begin{array}{lll}6.6 & \text { Summary } & 96\end{array}$

Notes and references $\quad 96$

$\begin{array}{ll}\text { Further reading } & 96\end{array}$

$\begin{array}{ll}\text { Questions and problems } & 96\end{array}$

$\begin{array}{lll}\text { Chapter } 7 & \text { Owners' equity, liabilities and working capital } & 99\end{array}$

$\begin{array}{lll}7.1 & \text { Introduction } & 99\end{array}$

$\begin{array}{llr}7.2 & \text { Financial structure } & 99\end{array}$

$\begin{array}{ll}7.3 \text { The concepts of equity and debt } & 101\end{array}$

$\begin{array}{ll}7.4 \text { Equity finance } & 103\end{array}$ 
Contents $\quad$ xi

$\begin{array}{lll}7.5 & \text { Debt finance } & 104\end{array}$

$\begin{array}{lll}7.6 & \text { Financial risk } & 105\end{array}$

$\begin{array}{lll}7.7 & \text { Short- and long-term finances } & 111\end{array}$

$\begin{array}{ll}7.8 \text { Cost of finance } & 112\end{array}$

$\begin{array}{lll}7.9 \text { Liquidity and solvency } & 112\end{array}$

$\begin{array}{ll}7.10 \text { Working capital } & 113\end{array}$

$\begin{array}{ll}7.11 \text { Flow of funds } & 117\end{array}$

7.12 Valuation of owners' equity, liabilities and working capital 120

$\begin{array}{ll}7.13 \text { Summary } & 122 \\ & 122\end{array}$

$\begin{array}{ll}\text { Notes and references } & 122\end{array}$

$\begin{array}{ll}\text { Further reading } & 122\end{array}$

$\begin{array}{ll}\text { Questions and problems } & 123\end{array}$

$\begin{array}{lll}\text { Chapter } 8 & \text { Value and profit under changing price levels } & 126\end{array}$

$\begin{array}{ll}8.1 \text { Introduction } & 126\end{array}$

$\begin{array}{ll}8.2 \text { Maintaining value intact } & 127\end{array}$

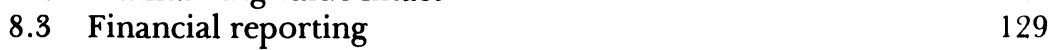

8.4 Comparing financial statements 134

8.5 Proposed adjustments to financial statements 136

$\begin{array}{ll}8.6 \text { Summary } & 139\end{array}$

$\begin{array}{ll}\text { Notes and references } & 140\end{array}$

$\begin{array}{ll}\text { Further reading } & 140\end{array}$

Questions and problems $\quad 140$

$\begin{array}{lll}\text { Chapter } 9 & \text { Review of value and profit } & 142\end{array}$

$\begin{array}{lll}9.1 \text { Introduction } & 142\end{array}$

9.2 The balance sheet as a valuation statement 143

$\begin{array}{lll}9.3 & \text { Goodwill } & 146\end{array}$

9.4 Valuation of the firm by means of share prices 148

9.5 Basis of valuation for decision-making 148

9.6 Example of alternative approaches to valuation 151

$\begin{array}{lll}9.7 & \text { Summary } & 155\end{array}$

Notes and references $\quad 155$

Further reading $\quad 155$

Questions and problems $\quad 156$

\section{PART II PLANNING}

Chapter 10 Concepts of planning 161

$\begin{array}{lll}10.1 & \text { Introduction } & 161\end{array}$

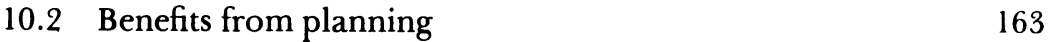

10.3 Statement of objectives $\quad 163$

10.4 Strategic and operating decisions 165

10.5 Data for planning-forecasting 166

10.6 Data for planning - search methods 166

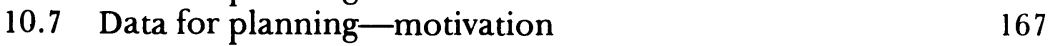

$\begin{array}{lll}10.8 & \text { Data for planning-relevant costs } & 168\end{array}$

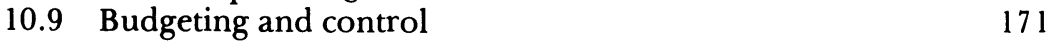

$\begin{array}{ll}10.10 \text { Summary } & 172\end{array}$

$\begin{array}{ll}\text { Notes and references } & 172\end{array}$ 
Further reading

Questions and problems

$\begin{array}{lll}\text { Chapter } 11 & \text { Pricing and output decisions } & 173\end{array}$

$\begin{array}{lll}11.1 & \text { Introduction } & 173\end{array}$

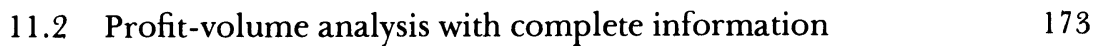

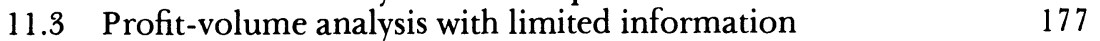

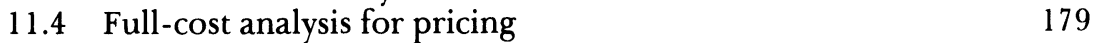

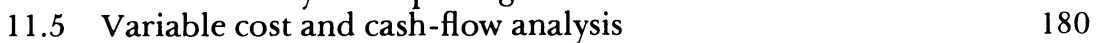

$\begin{array}{ll}11.6 & \text { Costs of capacity } \\ 11.7 & 183\end{array}$

$\begin{array}{lll}11.7 & \text { Summary } & 188\end{array}$

$\begin{array}{ll}\text { Notes and references } & 188\end{array}$

$\begin{array}{lr}\text { Further reading } & 188\end{array}$

$\begin{array}{ll}\text { Questions and problems } & 189\end{array}$

$\begin{array}{lll}\text { Chapter } 12 & \text { Long-term decisions } & 191\end{array}$

$\begin{array}{ll}12.1 & 191\end{array}$

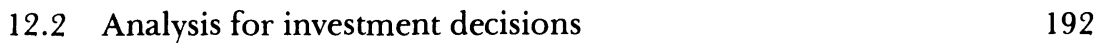

12.3 Allowing for the timing of the costs and benefits 193

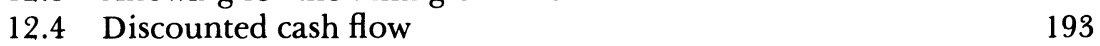

$\begin{array}{ll}12.5 \text { Payback and return on investment } & 197\end{array}$

12.6 Quality of the information in investment decisions 199

$\begin{array}{lll}12.7 & \text { Summary } & 206\end{array}$

Notes and references $\quad 206$

$\begin{array}{ll}\text { Further reading } & 207\end{array}$

$\begin{array}{ll}\text { Questions and problems } & 207\end{array}$

$\begin{array}{lll}\text { Chapter } 13 \text { Budgeting for the total firm } & 209\end{array}$

$\begin{array}{lll}13.1 & \text { Introduction } & 209\end{array}$

$\begin{array}{ll}13.2 \text { Decisions and budgets } & 210\end{array}$

$\begin{array}{ll}13.3 \text { Participation in budgeting } & 211\end{array}$

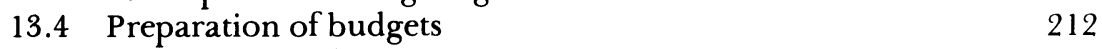

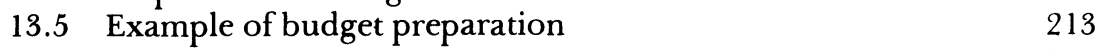

$\begin{array}{ll}13.6 & \text { Summary } \\ & 216\end{array}$

$\begin{array}{ll}\text { Notes and references } & 217\end{array}$

$\begin{array}{ll}\text { Further reading } & 217\end{array}$

$\begin{array}{ll}\text { Questions and problems } & 217\end{array}$

\section{PART III CONTROL}

$\begin{array}{lll}\text { Chapter } 14 & \text { Concepts of control } & 221\end{array}$

14.1 Introduction 221

14.2 Nature and objectives of control 222

14.3 Behavioural aspects of control 226

14.4 Information relevant for control 227

$\begin{array}{ll}14.5 \text { Summary } & 229\end{array}$

Notes and references $\quad 230$

Further reading 230

Questions and problems $\quad 230$ 
15.1 Introduction 231

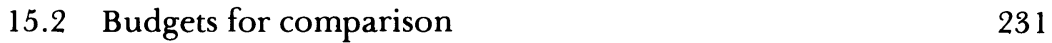

15.3 Operation of budgetary control 234

15.4 Interpretation of variances 236

15.5 Variance analysis and reports 239

$\begin{array}{lll}15.6 & \text { Summary } & 245\end{array}$

Notes and references $\quad 246$

Further reading $\quad 246$

Questions and problems $\quad 246$

Chapter 16 Interpretation of financial statements 248

$\begin{array}{lll}16.1 & \text { Introduction } & 248\end{array}$

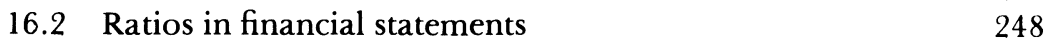

$\begin{array}{ll}16.3 \text { Ratio analysis } & 250\end{array}$

16.4 Illustration of ratio analysis 252

16.5 Groups of companies 255

$\begin{array}{lll}16.6 & \text { Summary } & 258\end{array}$

Notes and references $\quad 258$

Further reading $\quad 259$

Questions and problems $\quad 259$

Chapter 17 Disclosure of accounting information 262

$\begin{array}{lll}17.1 & \text { Introduction } & 262\end{array}$

17.2 Users and their needs 263

17.3 Development of disclosure 265

17.4 Disclosure requirements evaluated 268

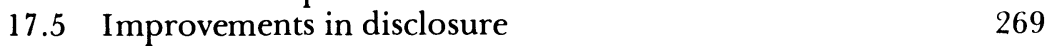

$\begin{array}{ll}17.6 \text { Summary } & 270\end{array}$

$\begin{array}{ll}\text { Notes and references } & 270\end{array}$

$\begin{array}{ll}\text { Further reading } & 271\end{array}$

$\begin{array}{ll}\text { Questions and problems } & 271\end{array}$

Appendix A Legal aspects of accounting for companies 273

$\begin{array}{lll}\text { Appendix B } & \text { Taxation } & 277\end{array}$

Appendix C Compound interest computations 283

Appendix D Published accounts of Marks \& Spencer Ltd 288

Author Index $\quad 303$

Subject Index $\quad 305$ 


\section{Introduction}

The book will provide a foundation in accounting for those courses where the emphasis is on analysis rather than description. We believe that the book could provide the basis for a one-year course for a specialist accounting student or a twoyear course for the student on a less specialised course such as business studies.

This should make it suitable for:

- undergraduate degree courses in business studies, accounting or economics

- H.N.C. and H.N.D. courses in business studies

- foundation courses required by the professional accounting bodies

- other courses providing an introduction to accounting, e.g. for managers or for postgraduate students on conversion courses in accounting or business studies.

We have written this book in an attempt to bridge a gap in the literature available to students of accounting. Until recent years introductory courses in accounting concentrated on the methods and techniques of the subject. Students who progressed to more advanced work were then introduced to the on-going discussion of the conceptual basis of accounting. The literature also exhibits this dichotomy. There are many books which deal in varying detail with technical aspects of accounting and also many at an advanced level with conceptual and theoretical topics. We believe that the teaching of accounting should conform to a logical pattern of introducing the conceptual foundations of the subject before building the superstructure of accounting methods. Thus we have written an introductory text which does not avoid the difficult conceptual problems but which attempts to present them in language and style which will be easily understood by those unfamiliar with accounting. We realise that in a single text it is not possible to cover the comparatively wide topic areas we have attempted and to reach a high level of sophistication simultaneously. Thus we have concentrated on giving a sound introduction to the topic areas and have supplemented each chapter with references to further reading of a more advanced nature.

We have taken as our starting-point the common definition of accounting as the measurement, recording and communication of economic data. Accounting has evolved from the needs of business and its concern is chiefly with the solution of business problems. The definition of business in this context is widely drawn to include any organisations which use accounting information, e.g. firms, government or trades unions. Business problems are usually multi-dimensional and their solution requires an understanding of a range of disciplines, in addition to accounting, such as economics, quantitative methods, law and behavioural science. Thus the study of accounting should ideally be related to the study of these other 
disciplines. We have in the text, wherever possible, highlighted the relationship of accounting to these other disciplines.

The accountant's area of major contribution is in the measurement of costs and benefits of business problems and the planning and control of business strategy and operations. To meet this challenge the subject-matter is continually evolving in an attempt to improve this measurement and to satisfy the changing demands of business. Our view is that the study of accounting can be an interesting and stimulating experience. We hope that the student will appreciate both the potential of accounting as a means of recording, analysis and communication of information, but also recognise the boundaries of the subject and the limitations of accounting measurement.

The book is divided into three parts: Measurement, Planning and Control. This division recognises that we have identified three clusters of problems in accounting, and that for clarity of exposition and analysis these clusters should be considered together. The parts on planning and control build on concepts developed in the measurement part, as both these processes clearly rely on measurement:

MEASUREMENT - the measurement of profit and value is regarded as a central theme of accounting; the conceptual basis is established in the first two chapters of Part I and the detailed implications are explored in the rest of Part I. Throughout Part I we emphasise that the need to provide published accounting information has been a strong influence on the measurement concepts adopted by accountants, but that many of these concepts are inappropriate for planning and control decisions.

PLANNING - the definition of planning adopted includes both short-term and long-term decision-making; this obviates the need for a distinction which is often made between decision-making and planning.

CONTROL - it is recognised that control and planning are closely linked but we have attempted to isolate the particular problems of control. These are seen as a process of monitoring and evaluation. Hence we include in this section the interpretation of financial statements and a discussion of the role and content of published financial information. This emphasises that the analysis of historical, or at best current, information is the major means of control in many organisations and is perhaps the only means of control available to external interested parties.

The content includes topics found in courses on financial and management accounting. Where only a financial accounting course is required it may be appropriate to consider Chapters 16 and 17 in addition to Part I. The book incorporates several features which we hope will facilitate its use as a textbook for a course. Each Part is introduced with a chapter on the concepts to be explored in that Part and it is recommended that each subsequent chapter is read in conjunction with the concepts chapter. We have attempted to build a coherent structure by consciously linking each chapter, either through the summary of the preceding chapter or in the introduction to the chapter. This should help to demonstrate the coherence of a lecture programme based on the chapters of the book. At the end of each chapter there are notes and references relating to points in the chapters, suggestions for further reading and a set of questions and problems. The further reading has been selected to assist the student who wishes to go into more depth in a particular area and would be appropriate reading for a seminar paper based on a particular aspect of the chapter. As well as going into more depth a student may be interested in learning more about the wide variety of existing book-keeping techniques and specialist accounting systems, such as those for partnership, which 
are used for handling accounting data. We have analysed the principles of the structure and processing of accounting data in Chapters 3 and 4 but have not considered in any detail the numerous possible book-keeping applications. We hope that with the general principles developed in these chapters, students will be able to understand any specialist applications they may encounter in practice. As teachers we recognise that one of the major obstacles to understanding accounting is its use of a terminology which is in many areas imprecise and ambiguous. We have attempted to be consistent in our use of terminology and we must admit the exercise has increased our sympathy towards students who are commonly faced with various usages of terms such as capital, profit, cost, returns or stock. As a learning and a teaching aid we have included as the first of the questions at the end of each chapter a review of important terminology used in the chapter. This and the other questions and problems have been designed to provide a basis for personal assessments, seminar papers or seminar and tutorial discussion.

Finally we would like to recommend the idea of triple authorship for anyone who wishes to embark on a critical self-analysis of what he thinks he understands about accounting, but not for anyone who wishes to write a book in a reasonable time. We would like to acknowledge our debt to our long-suffering wives and children, and to all those who helped with the typing of the manuscript. 